University of Louisville

ThinkIR: The University of Louisville's Institutional Repository

Electronic Theses and Dissertations

$12-2016$

\title{
Immune monitoring in recipients of combined living donor kidney and hematopoietic stem/facilitating cell transplants.
}

Mark DeWayne Badder

University of Louisville

Follow this and additional works at: https://ir.library.louisville.edu/etd

Part of the Biological Phenomena, Cell Phenomena, and Immunity Commons, and the Medical Immunology Commons

\section{Recommended Citation}

Badder, Mark DeWayne, "Immune monitoring in recipients of combined living donor kidney and hematopoietic stem/facilitating cell transplants." (2016). Electronic Theses and Dissertations. Paper 2614.

https://doi.org/10.18297/etd/2614

This Master's Thesis is brought to you for free and open access by ThinkIR: The University of Louisville's Institutional Repository. It has been accepted for inclusion in Electronic Theses and Dissertations by an authorized administrator of ThinkIR: The University of Louisville's Institutional Repository. This title appears here courtesy of the author, who has retained all other copyrights. For more information, please contact thinkir@louisville.edu. 


\title{
IMMUNE MONITORING IN RECIPIENTS OF COMBINED LIVING DONOR KIDNEY AND HEMATOPOIETIC STEM/FACILITATING CELL TRANSPLANTS
}

\author{
By \\ Mark DeWayne Badder \\ B.S., University of Louisville, 2009
}

\begin{abstract}
A Thesis
Submitted to the Faculty of the School of Medicine of the University of Louisville In Partial Fulfillment of the Requirements For the Degree of
\end{abstract}

Master of Science in Microbiology and Immunology

\author{
Department of Microbiology and Immunology \\ School of Medicine \\ University of Louisville \\ Louisville, Kentucky
}

December 2016 
Copyright 2016 by Mark DeWayne Badder

All rights reserved 

IMMUNE MONITORING IN RECIPIENTS OF COMBINED LIVING DONOR KIDNEY AND HEMATOPOIETIC STEM/FACILITATING CELL TRANSPLANTS

\author{
By \\ Mark DeWayne Badder \\ B.S., University of Louisville, 2009
}

A Thesis Approved on

November 14, 2016

by the following Thesis Committee:

Thesis Director

Dr. Suzanne T. Ildstad

Thesis Co-Director

Dr. Esma S. Yolcu

Dr. Nathan W. Schmidt 


\section{DEDICATION}

I would like to dedicate this work to my son Fox, who is the light of my life. May this work serve to inspire you to reach for the clouds, and capture them. 


\section{ACKNOWLEDGEMENTS}

I would like to extend my deepest appreciation to Dr. Suzanne Ildstad for taking me on as a student and allowing me to work with such a rare and amazing project. Her work in human stem cell transplants will be a paradigm shift in organ transplantation and I am overjoyed with having the opportunity to be a part of that, doing what I love most with flow cytometry.

I want to thank Dr. Esma Yolcu for all of the time and effort she spent on me at every step along the way in this endeavor. She has been invaluable with her guidance and encouragement. I could not complete this degree without her direction and tough love approach. Dr. Yolcu helped to strengthen me in a way that cannot be learned in a classroom setting.

I also want to acknowledge Dr. Schmidt for taking the time away from his valuable work to serve on my committee.

I want to thank everyone at the Institute for Cellular Therapy, Northwestern Memorial Hospital, and Novartis for all the support and scientific challenges they provided.

Last, but not least, I want to show my appreciation to the Department of Microbiology \& Immunology for making this degree challenging and a gratifying experience. 


\section{ABSTRACT \\ IMMUNE MONITORING IN RECIPIENTS OF COMBINED LIVING DONOR KIDNEY AND HEMATOPOIETIC STEM/FACILITATING CELL TRANSPLANTS \\ Mark DeWayne Badder}

November 14, 2016

Solid organ transplantation coupled with a hematopoietic stem cell transplant from the organ donor allows for the recipient to cease immunosuppressive therapy after transplant via a chimeric immune system. This beneficial effect of stem cell transplants is negatively affected by graft versus host disease (GVHD). Better understanding of the donor and recipient's immune system is vital to mitigating graft versus host disease and induction of donor chimerism without GVHD. In this study, flow cytometry was used to characterize immune cells of the recipients’ before and up to eighteen months post transplantation. The recipients were categorized into their respective chimeric groups. Fully durable chimeric subjects did not reconstitute naïve T cells to pre-transplant levels by eighteen months post-transplant whereas the transiently chimeric subjects reconstituted. The goal was to find an immune cell biomarker for chimerism but due to the limited number of transiently chimeric subjects, the data showed no significant difference. 
TABLE OF CONTENTS

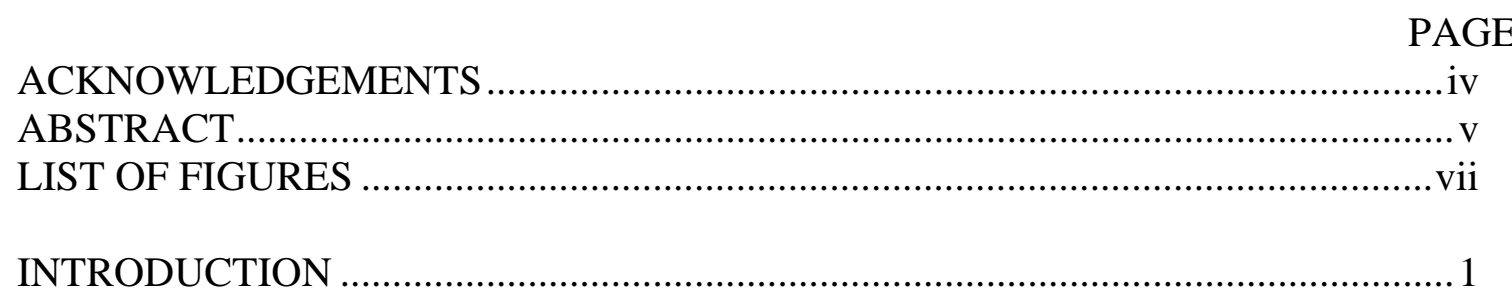

Hypothesis...........................................................................................

METHODS AND MATERIALS.............................................................................

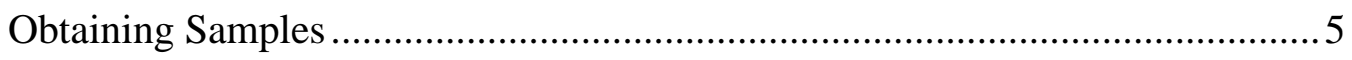

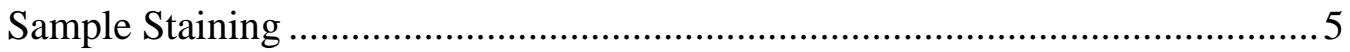

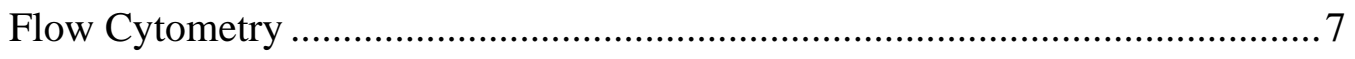

Statistical Analysis...................................................................................

RESULTS …

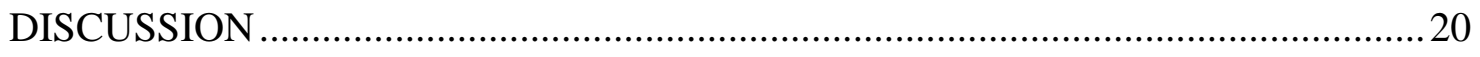

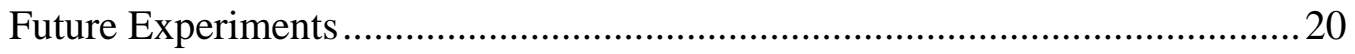

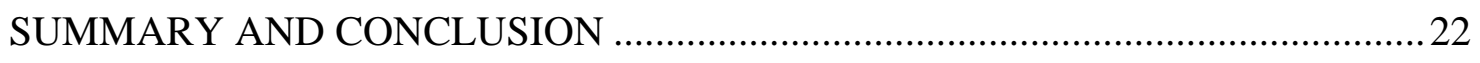

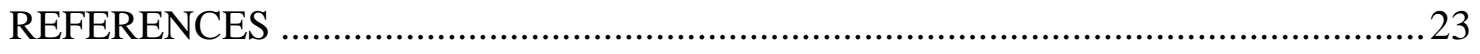

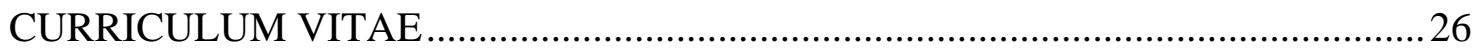




\section{LIST OF FIGURES}

FIGURE

PAGE

1. Algorith for conditioning, transplant, and maintenance immunosuppression ..........4

2. Lineage populations for the fully durable chimeric group.................................. 13

3. Lineage populations for the transiently chimeric group ................................... 14

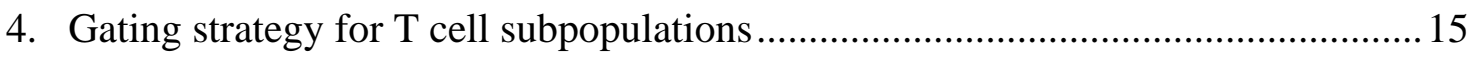

5. $\mathrm{CD}^{+}$and $\mathrm{CD}^{+}$subpopulations for the fully durable chimeric group ....................16

6. $\mathrm{CD}^{+}$and $\mathrm{CD}^{+}$subpopulations for the transiently chimeric group.......................17

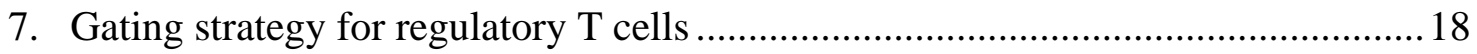

8. $\mathrm{CD}^{+}$regulatory $\mathrm{T}$ cells for each time point as an average within the fully durable and transiently chimeric groups .................................................. 19 


\section{INTRODUCTION}

Hematopoietic stem cell (HSC) transplantation in conjunction with a solid organ transplant is in its infancy but has shown very promising results [1]. One of the major concerns with HSC transplantation is graft versus host disease (GVHD) [2]. The donor

cells will mount an immune response against the recipient, ultimately causing rejection of transplanted cells and organ. Without HSC transplantation along with the solid organ transplant, the recipient is confined to a regiment of constant immunosuppressive drug therapy for the remainder of his/her life [3]. This poses negative side effects which include a reduced immune system and an increased risk of developing cancer and opportunistic infections [4]. However, with the HSC transplant, the recipient will still take immunosuppressive drugs for a short period of time and then cease treatment to allow time for the donor and recipient cells to form a chimeric immune system where both the recipient and donor cells are active and cooperative [5].

Due to the toxicity of immunosuppressive therapies [6] [7], Dr. Ildstad and her group have pioneered a HSC transplant model, known as facilitating cell treatment (FCRx), which relies on the enrichment of $\mathrm{CD}^{+} / \mathrm{TCR}^{-}$facilitating cells (FC) and HSCs by depleting GVHD-producing cells. FCRx transplants from the donor of a living kidney have been shown to induce a chimeric immune system in recipients of combined kidney and FCRx transplants [8]. This model is currently in FDA clinical trial for humans and 
its aim is to eliminate the long term usage of immunosuppressive therapies via chimerism [9] [10].

The conditioning for FCRx transplant comprises a number of chemical and radiation treatments. Fludarabine is administered at days $-4,-3$, and -2 pre-transplant and interferes with DNA synthesis. Cyclophosphamide (Cy) is given at day -3 and interferes with DNA replication. Tacrolimus, which inhibits IL-2 production to inhibit the development and proliferation of T cells, and mycophenolate mofetil (MMF), which inhibits an enzyme needed for the growth of $\mathrm{T}$ and $\mathrm{B}$ cells, treatment starts at day -2 and is continued after transplantation. An irradiation of 200 cGy total body irradiation (TBI) is performed at day -1 . On day 0 , the kidney transplant is performed and the FCRx infusion is performed day +1 . Another treatment of Cy is administered at day +3 . At this point, the recipient's immune system is reduced to very low levels of white blood cells (WBC). Engraftment of donor cells and recovery of recipient cells is monitored and determined at certain time points post-transplant. MMF is ceased at 6 months posttransplant and tacrolimus at 12 months if a stable level of donor chimerism is determined [5]. A timeline of conditioning and events is presented in Figure 1.

Massachusetts General Hospital (MGH) and Stanford are also working with a combined HSC and organ transplant model to achieve chimerism. The MGH group concentrates on tolerance via achieving transiently mixed chimerism [11]. Stanford achieved a persistent mixed chimerism in combined transplant subjects that were human leukocyte antigen (HLA) matched donor and recipient but zero chimerism in HLA mismatched transplants [11]. The Northwestern group with the Institute of Cellular Therapeutics (ICT, University of Louisville) has thirty five subjects that received a 
combined transplant and eighteen recipients that have successfully ceased all immunosuppressive therapies with full donor chimerism induction.

While the FCRx transplant model aids in inducing chimerism, not all subjects in the clinical trial fully develop durable chimerism. Within the scope of my work, there were eight human subjects that obtained a fully durable chimerism (100\% donor DNA in recipient $\mathrm{CD}^{+}$cells and whole blood), four that showed chimerism after transplantation and infusion but regressed between months one and three post transplantation and are termed transient, and one that never developed chimerism. The knowledge gap that we addressed in this work is to determine if there are differences in certain immune cell populations between the fully durable and transiently chimeric groups post transplantation.

\section{Hypothesis:}

Characterizing the immune cell populations of the recipient pre- and posttransplantation is important to determine if varying levels of chimerism result in differences in the repopulation of immune cell subsets. Regulatory T cells are involved in downregulating the immune system [12] and may be involved in aiding induction of chimerism long term. The hypothesis was that we would find a divergence of at least one immune cell type between the two chimeric groups, fully durable and transiently chimeric, that would be a novel biomarker for chimerism. 
Figure 1.

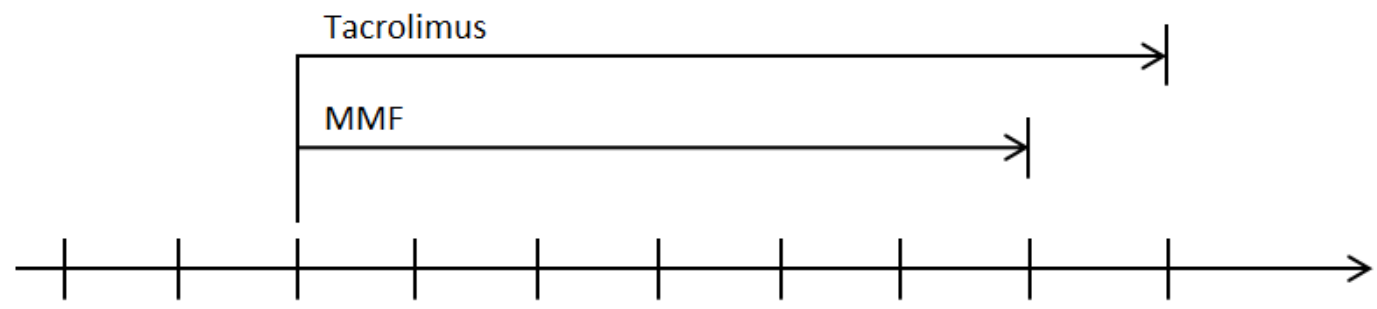

\begin{tabular}{|c|c|c|c|c|c|c|c|c|c|}
\hline Day & Day & Day & Day & Day & Day & Day & Day & Month & Month \\
\hline-4 & -3 & -2 & -1 & 0 & +1 & +2 & +3 & +6 & +12 \\
\hline $\begin{array}{l}\frac{0}{0} \\
\frac{.0}{0} \\
\frac{\pi}{0} \\
\frac{\pi}{0} \\
\frac{3}{4}\end{array}$ & 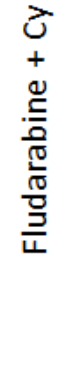 & 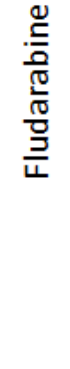 & 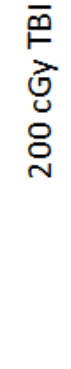 & 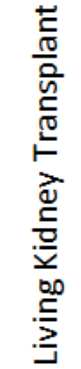 & 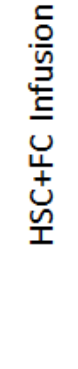 & & $\vec{U}$ & & \\
\hline
\end{tabular}

Figure 1. Algorith for condition, kidney and FCRx transplant, and maintenance immunosuppression. 


\section{METHODS AND MATERIALS}

Institutional Review Boards (IRB) at Northwestern University and the University of Louisville approved all protocols in addition to the FDA (IDE 13947 \& 7392). Donors and recipients provided informed consent for admission into the clinical trial program.

\section{Obtaining Samples:}

Whole blood human samples from both recipient and donor were obtained in a Beckson Dickson (BD) acid citrate dextrose vacutainer tube from Northwestern Memorial Hospital in Chicago, Illinois and delivered the next day to the University of Louisville, Louisville, Kentucky. A complete blood count (CBC) was performed in duplicate and the average WBC was recorded at receipt of each sample on a Horiba Micros 60 cell counter.

\section{Sample Staining:}

Third party, healthy human donor whole blood was used for unstained and single color compensation controls to properly set the parameters on the flow cytometer and followed staining steps for tubes that did not have intracellular markers added.

Samples were stained in Fisher flow tubes using 20 $\mu$ l of BD extracellular antibodies that were previously titrated on third party, healthy human donor whole blood for optimal staining. Upon antibody staining, the cells were incubated at $4^{\circ} \mathrm{C}$ for 30 minutes. After incubation, the cells were gently ratcheted to break up any pellets that may have occurred during incubation and washed with $2 \mathrm{ml}$ of an in-house flow stain 
buffer and the tubes were placed in a centrifuge set for $200 \mathrm{~g}, 4^{\circ} \mathrm{C}$, for 5 minutes. The flow stain buffer was made by adding $1.8 \mathrm{~g}$ sodium bicarbonate from Sigma-Aldrich (catalog \#S8875), 5.0g Bovine Serum Albumin from Sigma-Aldrich (catalog \#A7030), 5.0g sodium azide from Sigma-Aldrich (catalog \#S2002), to a Hank’s Balanced Salt Solution from Lonza BioWhittaker (catalog \#10547F), which was diluted to a 1X concentration with endotoxin free water obtained from a Millipore water purification system. After centrifugation, the supernatant was decanted from the tubes, ratcheted to break up pellets, and washed with 1ml Fixation/Permeabilization Buffer created using eBioscience Fixation/Permeabilization Concentrate (catalog \#00-5123-43) and Fixation/Permeabilization Diluent (catalog \#00-5223-56) and vortexed. This step was used for all samples since some underwent intracellular staining and consistency in preparation was desired. The cells were incubated at $4^{\circ} \mathrm{C}$ in the dark for 1 hour if no intracellular markers were to be used or 15 hours under the same conditions if intracellular markers were to be added. Upon completion of the incubation, $2 \mathrm{ml}$ of the in-house flow stain buffer was added and the cells were placed in a centrifuge set for $200 \mathrm{~g}, 4^{\circ} \mathrm{C}$, for 5 minutes. The supernatant was decanted and the tubes ratcheted before adding 2ml of Permeabilization Buffer from eBioscience (catalog \#00-833-56) diluted to a 1x concentrate with Dulbecco's phosphate-buffered saline (DPBS) from BioWhittaker (catalog \#17-512Q) and placed in a centrifuge set for $200 \mathrm{~g}, 4^{\circ} \mathrm{C}$, for 5 minutes before decanting the supernatant and the tubes ratcheted.

Subject sample cells that required intracellular staining had $20 \mu \mathrm{l}$ of $10 \%$ goat serum from Sigma-Aldrich (catalog \#G9023) added as a blocking agent and incubated at $4^{\circ} \mathrm{C}$ in the dark for 30 minutes, then $\mathrm{BD}$ intracellular antibodies were added to the tubes 
and the tubes were incubated again at $4^{\circ} \mathrm{C}$ in the dark for 30 minutes. After incubation, 2ml of diluted Permeabilization Buffer was added to the tubes with intracellular markers. The supernatant was decanted and the tubes ratcheted.

The sets of tubes with and without intracellular markers were washed with $2 \mathrm{ml}$ of the in-house flow stain buffer and the cells were placed in a centrifuge set for $200 \mathrm{~g}, 4^{\circ} \mathrm{C}$, for 5 minutes. The supernatant was decanted and the tubes ratcheted. $400 \mu \mathrm{l}$ of the inhouse flow stain buffer was added to the tubes and they were vortexed before flow cytometry acquisition.

\section{Flow Cytometry:}

The prepared controls and subject samples were acquired on a BD LSRII flow cytometer with a threshold set to eliminate any remaining red blood cells still present in any of the tubes. The flow cytometer rate was set at medium to reduce the possibility of doublets occurring in the flow cell. Forward Scatter (FSC) and Side Scatter (SSC) were adjusted on the unstained subject sample tube after compensation was set. Each tube was acquired until 100,000 total events were recorded.

Samples were analyzed using BD FACSDiva software. The number of CD4 ${ }^{+}$ regulatory $\mathrm{T}$ cells was recorded along with the total number of events. The absolute cell number was calculated by multiplying the WBC number by the percent of the cell population of interest.

\section{Statistical Analysis:}

Subjects were grouped into their respective chimerism groups and the average among the chimeric group was determined for each time point. Standard error of the mean was calculated and used for generating error bars in the graphs. A two-tailed 
Student's t-test with unequal variance was performed to compare the fully durable to the transiently chimeric groups at each time point. This was because the two chimeric groups are unequal in the number of subjects in their respective groups. A $p$-value of 0.05 or lower is considered significant for the data presented. 


\section{RESULTS}

Clinical subjects were sorted into sets of chimeric groups. Fully durable chimerism includes subjects that developed a homeostatic chimeric immune system between the recipient and the donor. These subjects were weaned off of immunosuppressive therapies by twelve months post kidney transplantation. Transiently chimeric subjects started showing decreased levels of chimerism between months one and three post combined kidney/FCRx transplant, but showed zero percent chimerism in their whole blood by twelve months post transplantation. These subjects have to continue immunosuppressive therapies. One subject never obtained a level of chimerism above zero percent. In total, there are eight subjects that are fully chimeric, four that are transient, and one that never became chimeric and the chimeric groups are listed in Table 1.

Lineage reconstitution of FCRx recipients was monitored and assessed. Due to the conditioning, the absolute cell number of $\mathrm{CD}^{+}$cells showed a decrease posttransplantation. B cells and NK cells recovered faster than T cells and, by six months post-transplant, were larger in number than pre-transplant levels in both chimeric groups and are shown in Figures 2 and 3 [5]. Interestingly, the transiently chimeric subjects' NK cells exceeded the pre-transplant absolute cell number by eighteen months posttransplantation. Since the transiently chimeric subjects are no longer tolerant, their NK 
cells could be mounting a response to the foreign graft including donor cells [13].

$\mathrm{CD}^{+}$and $\mathrm{CD}^{+}$subpopulations of $\mathrm{CD}^{+} \mathrm{T}$ cells were also characterized. Effector memory cells ( $\mathrm{Tem}$ ) were defined as $\mathrm{CD} 45 \mathrm{RA}^{-} / \mathrm{CD} 45 \mathrm{RO}^{+} / \mathrm{CD} 2 \mathrm{~L}^{\text {low }}$, central memory cells $\left(\mathrm{T}_{\mathrm{cm}}\right)$ as CD45RA ${ }^{-} / \mathrm{CD}_{4} 4 \mathrm{RO}^{+} / \mathrm{CD} \mathrm{L}^{\text {high }}$, effector cells $\left(\mathrm{T}_{\text {eff }}\right)$ as

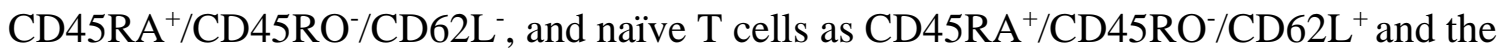
gating strategy is shown in Figure 4. Within twelve months post-transplantation, the $\mathrm{CD}^{+}$and $\mathrm{CD}^{+} \mathrm{T}_{\mathrm{em}}, \mathrm{T}_{\mathrm{cm}}$, and $\mathrm{T}_{\text {eff }}$ subpopulations reconstituted to a level not significantly different than pre-transplant cell numbers for both chimeric groups as shown in Figures 5 and 6. Naïve $\mathrm{CD}^{+}$subpopulations, however, did not return to pre-transplant levels and is reflected in both fully durable and transiently chimeric groups [5]. The naïve $\mathrm{CD}^{+}$cells did not return to pre-transplant levels for the fully durable group but did return to a similar state for the transiently chimeric subjects by nine months posttransplant.

Regulatory $\mathrm{T}$ cells were defined as $\mathrm{CD}^{+} / \mathrm{CD} 25^{+} / \mathrm{FoxP}^{+}$and our gating strategy is listed in Figure 7. Comparing the fully durable to the transiently chimeric groups, I found there to be no significant difference pre combined kidney/FCRx transplant, which was to be expected. Three months post-transplant, data showed that both chimeric groups had drastically reduced levels of regulatory T cells due to the subjects' irradiation and immunosuppressive therapies. Considering Figure 8, once MMF was discontinued, a divergence of the regulatory $\mathrm{T}$ cells was observed between fully durable and transiently chimeric subjects, which became more prominent at twelve months, when tacrolimus was discontinued, and even more at eighteen months post-transplantation, though there was no significant difference. The transiently chimeric subjects’ regulatory T cells never 
completely recovered to pre-transplant levels and remained similar to their three month post-transplant levels. 


\section{Table 1.}

$\underline{\text { Chimeric Subject Groups of Living Kidney and FCRx Transplant }}$

\begin{tabular}{|c|c|c|}
\hline Subject & Chimeric Group & $\begin{array}{c}\text { Month } 12 \text { Percent Whole Blood Donor } \\
\text { Chimerism }\end{array}$ \\
\hline NW1 & Transient & $0 \%$ \\
\hline NW2 & Off Study & Off Study \\
\hline NW3 & Fully Durable & $100 \%$ \\
\hline NW4 & Transient & $0 \%$ \\
\hline NW5 & Fully Durable & $100 \%$ \\
\hline NW6 & Fully Durable & $100 \%$ \\
\hline NW7 & Fully Durable & $100 \%$ \\
\hline NW8 & Fully Durable & $100 \%$ \\
\hline NW9 & 0\% Chimeric & $0 \%$ \\
\hline NW10 & Fully Durable & $100 \%$ \\
\hline NW11 & Transient & $0 \%$ \\
\hline NW12 & Transient & $10 \%$ \\
\hline NW13 & Off Study & Off Study \\
\hline NW14 & Fully Durable & $100 \%$ \\
\hline NW15 & Fully Durable & $100 \%$ \\
\hline
\end{tabular}


Figure 2.

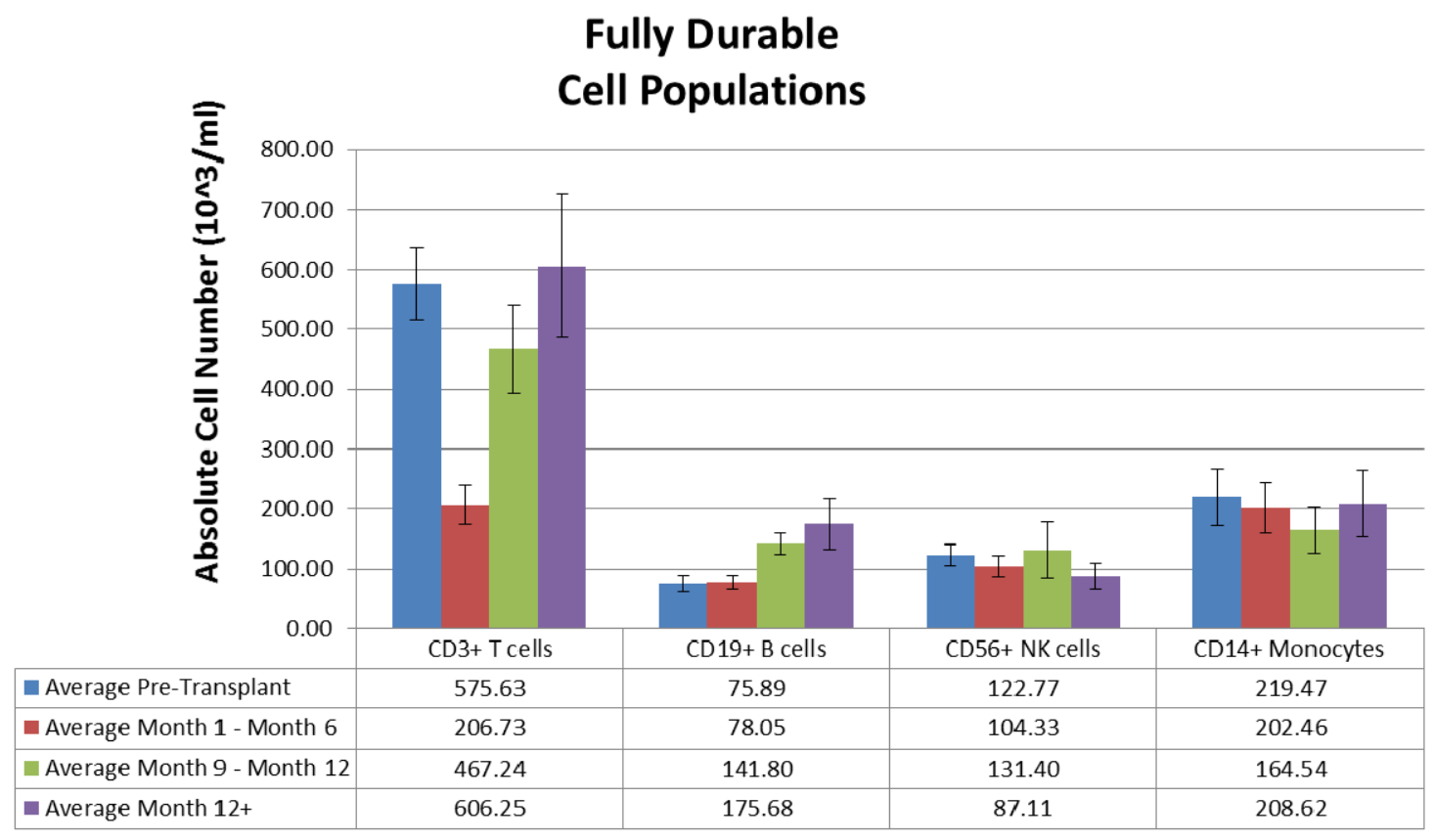

Figure 2. Lineage populations for the fully durable chimeric group. $\mathrm{CD}^{+}, \mathrm{CD} 19^{+} \mathrm{B}$ cells, CD56 ${ }^{+}$NK cells, and CD14 ${ }^{+}$monocytes absolute cell numbers are shown. This data was previously published in [5]. 


\section{Figure 3.}

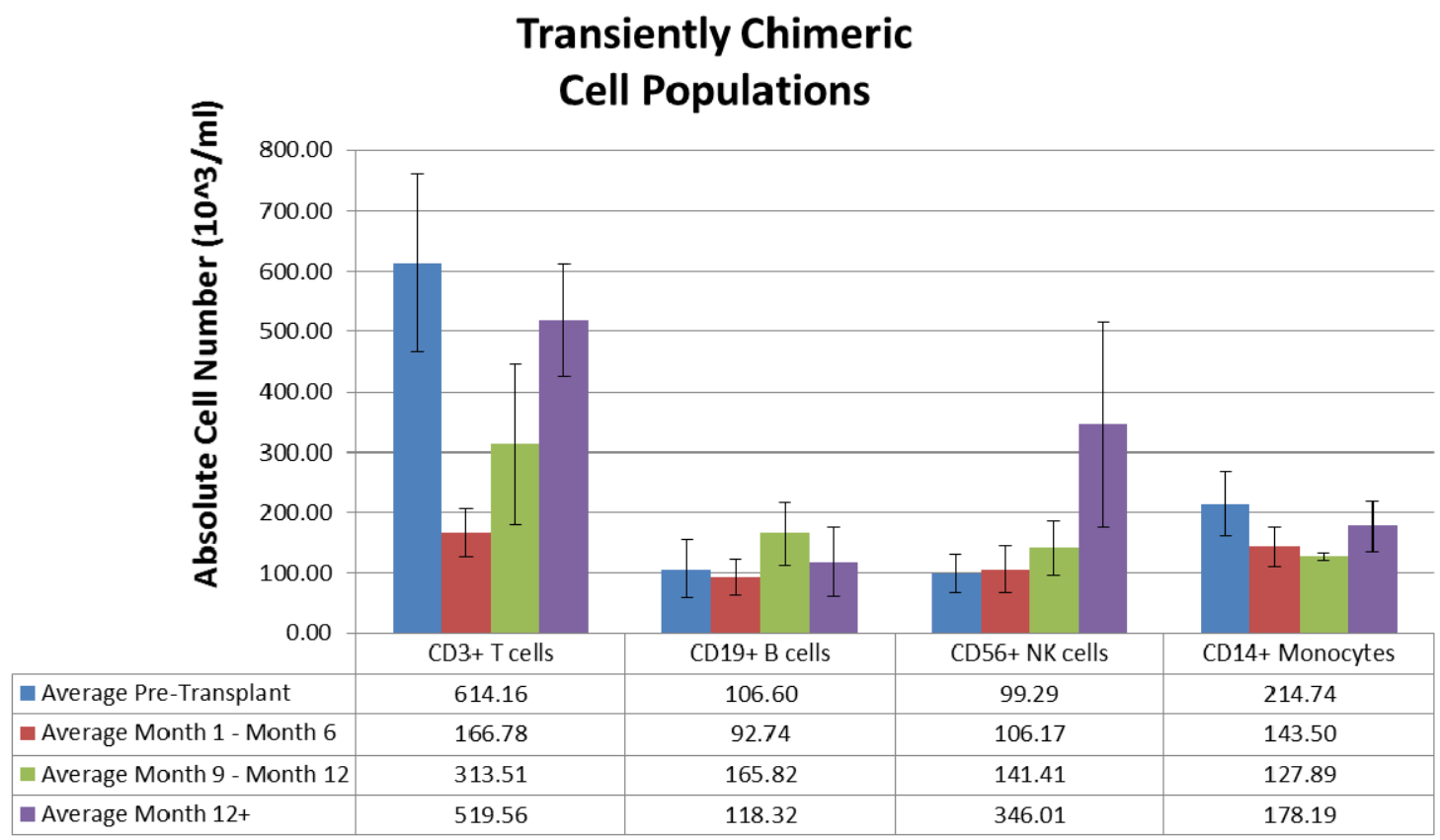

Figure 3. Lineage populations for the transiently chimeric group. $\mathrm{CD}^{+}, \mathrm{CD} 19^{+} \mathrm{B}$ cells, $\mathrm{CD}^{+} 6^{+} \mathrm{NK}$ cells, and CD14 ${ }^{+}$monocytes absolute cell numbers are shown. This data was previously published in [5]. 
Figure 4.

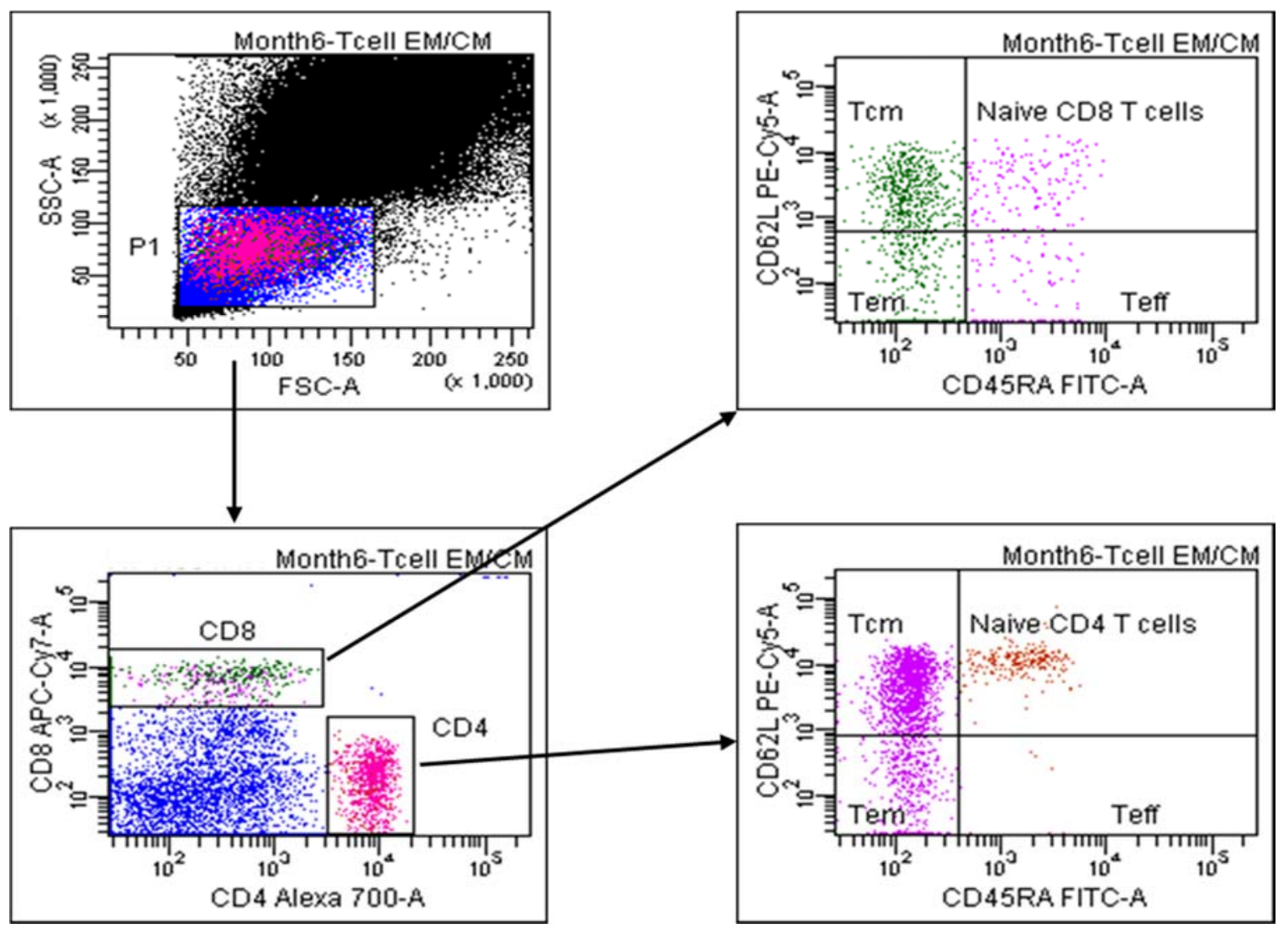

Figure 4. The gating strategy for T cell subpopulations on the BD LSRII is shown.

lymphocytes were selected (P1 gate in top left dot plot), followed by $\mathrm{CD}^{+}$and $\mathrm{CD} 8^{+}$ (bottom left dot plot) followed by effector memory cells ( $\mathrm{Tem}_{\mathrm{em}}$ as CD45RACD45RO ${ }^{+}$/ CD62L ${ }^{\text {low }}$, central memory cells $\left(\mathrm{T}_{\mathrm{cm}}\right)$ as $\mathrm{CD} 45 \mathrm{RA}^{-} / \mathrm{CD} 45 \mathrm{RO}^{+} / \mathrm{CD} \mathrm{L}^{\text {high }}$, effector cells ( $\mathrm{T}_{\text {eff }}$ ) as $\mathrm{CD} 45 \mathrm{RA}^{+} / \mathrm{CD} 45 \mathrm{RO}^{-} / \mathrm{CD} \mathrm{L}^{-}$, and naïve $\mathrm{CD}^{+}$and $\mathrm{CD}^{+} \mathrm{T}$ cells as $\mathrm{CD}^{2} 5 \mathrm{RA}^{+} / \mathrm{CD} 45 \mathrm{RO}^{-} / \mathrm{CD} 62 \mathrm{~L}^{+}$. 


\section{Figure 5.}

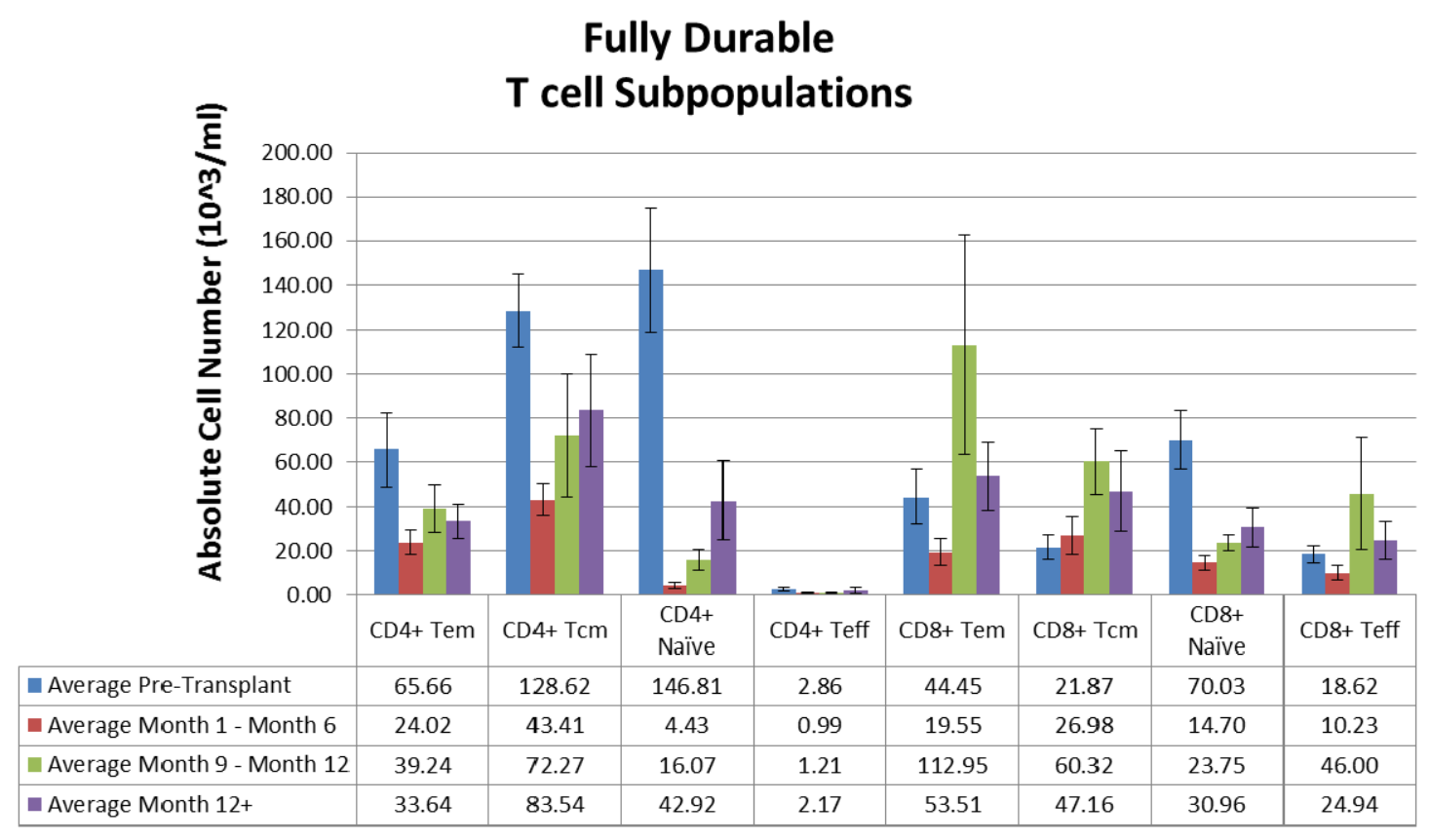

Figure 5. $\mathrm{CD}^{+}$and $\mathrm{CD}^{+}$subpopulations for the fully durable chimeric group. $\mathrm{T}_{\mathrm{em}}$, $\mathrm{T}_{\mathrm{cm}}$, naïve, and $\mathrm{T}_{\text {eff }}$ absolute cell numbers are shown. Naïve CD4 ${ }^{+}$and naïve $\mathrm{CD} 8^{+}$cells did not return to pre-transplant levels. This data was previously published in [5]. 


\section{Figure 6.}

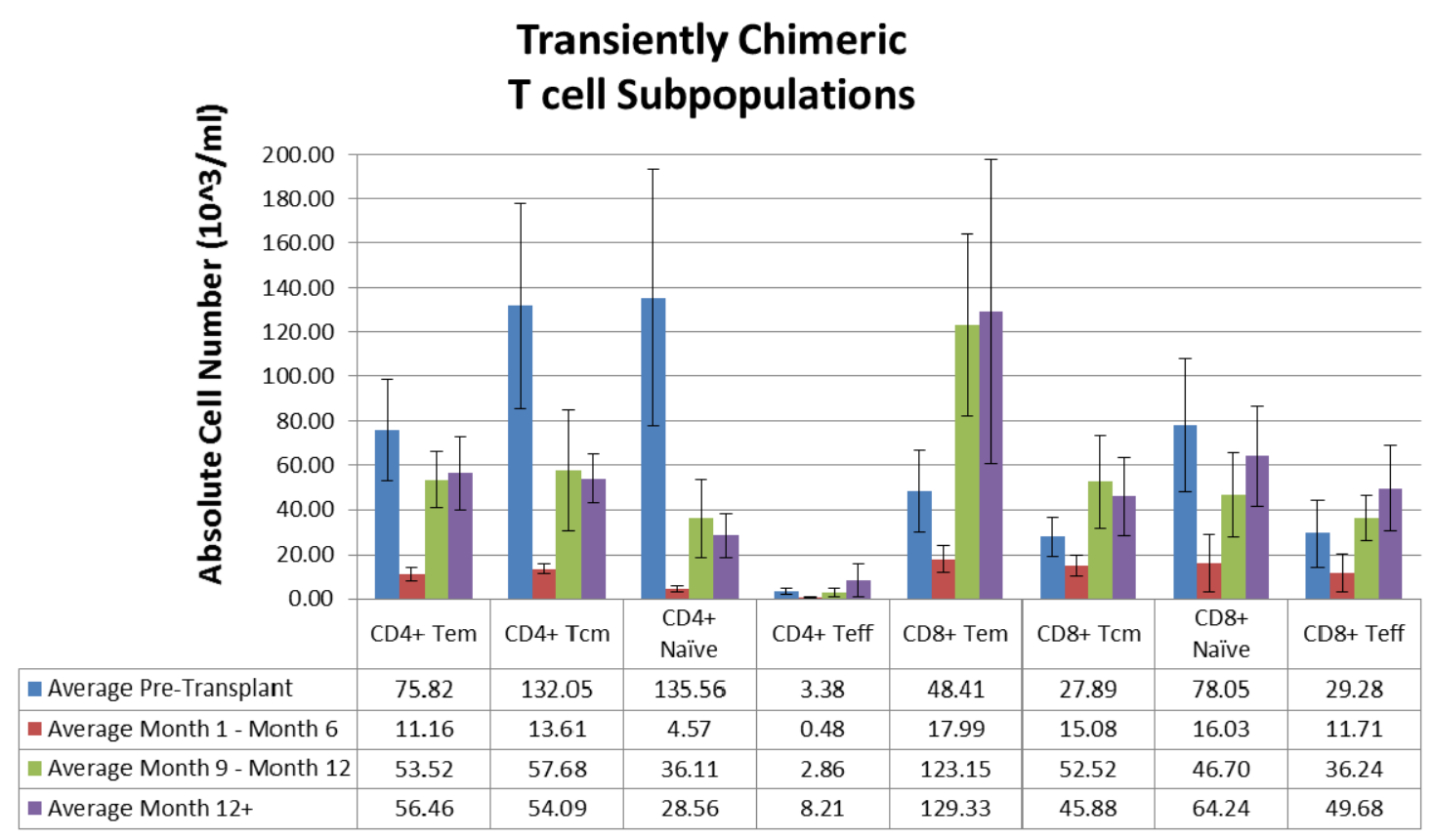

Figure 6. $\mathrm{CD}^{+}$and $\mathrm{CD}^{+}$subpopulations for the transiently chimeric group. $\mathrm{T}_{\mathrm{em}}, \mathrm{T}_{\mathrm{cm}}$, naïve, and $T_{\text {eff }}$ absolute cell numbers are shown. This data was previously published in [5]. 
Figure 7.

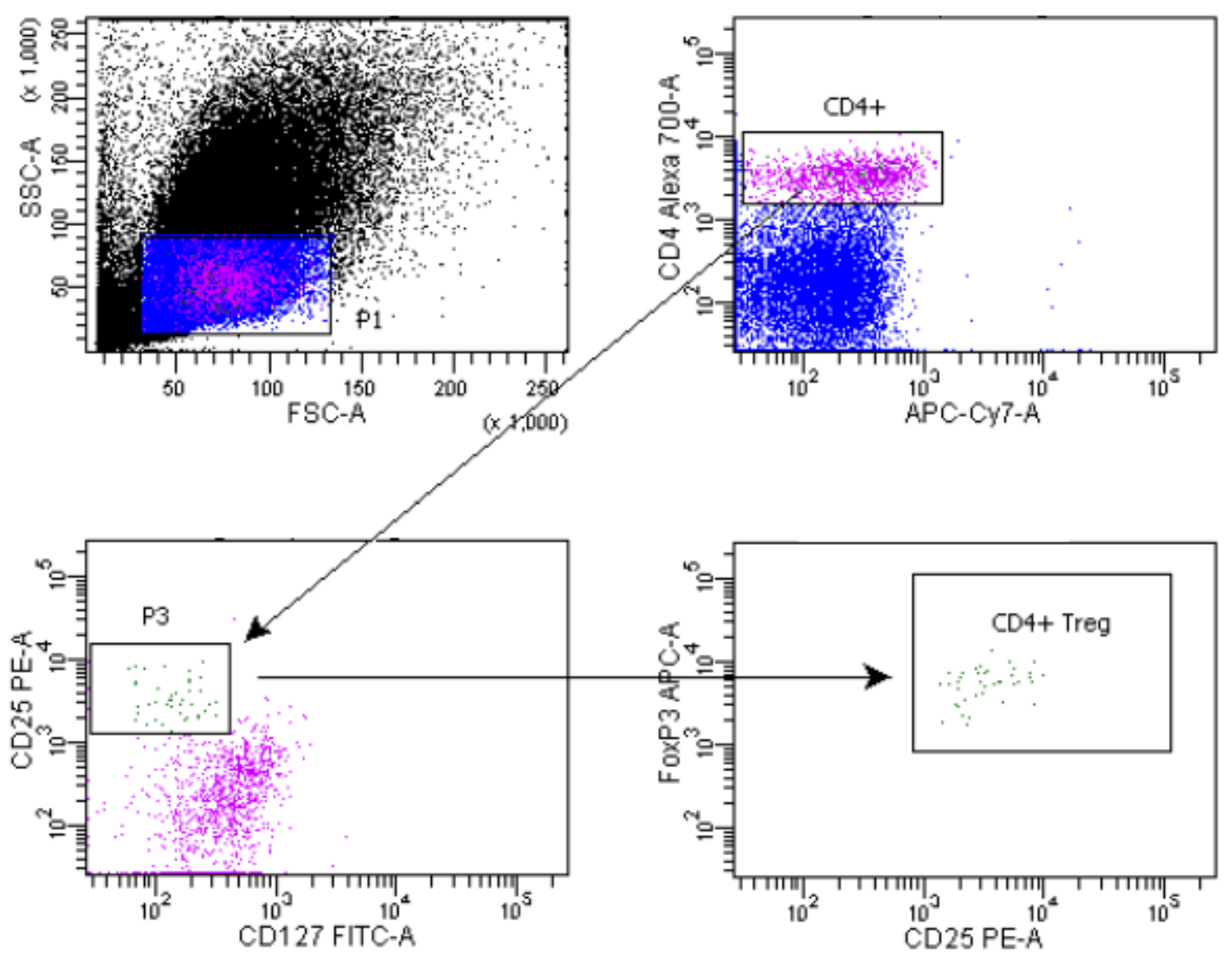

Figure 7. The gating strategy for regulatory T cells on the BD LSRII is shown.

Lymphocytes were selected (P1 gate in the top left dot plot), followed by CD4 ${ }^{+}$cells (top right dot plot), then $\mathrm{CD}^{2} 5^{+}$cells (bottom left dot plot), and finally CD25 $5^{+} \mathrm{FoxP}^{+}$cells $\left(\mathrm{CD}^{+} / \mathrm{CD}^{2} 5^{+} / \mathrm{FoxP}^{+}\right.$regulatory T cells). 
Figure 8.

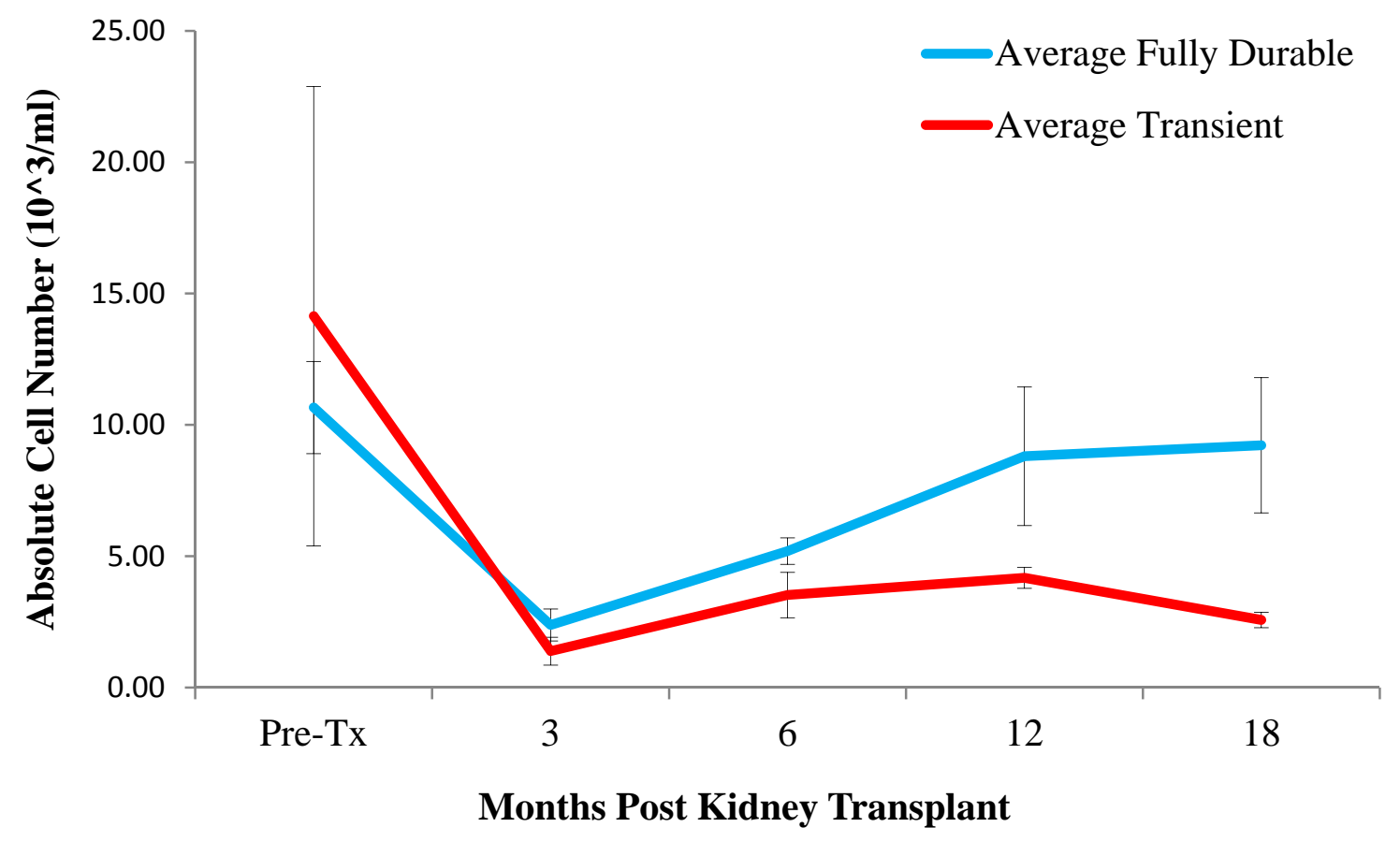

Figure 8. $\mathrm{CD}^{+}$regulatory T cells shown for each time point as an average within the fully durable and transiently chimeric groups. Though the transient subjects had higher levels of regulatory $\mathrm{T}$ cells, than the fully durable group, pre-transplant and lower levels post-transplant, there was no significant difference. 


\section{DISCUSSION}

Studies on chimeric immune systems have not been able to show a biomarker that accurately predicts successful, durable chimerism after the cessation of immunosuppressive therapy. Consequentially, $80 \%$ of subjects that are weaned off of immunosuppression undergo rejection and must be placed on immunosuppressive therapy again [14] [15]. This impact is of vital consequence because rejection has previously been linked to the survival of the sold organ transplant [16].

The scope of this thesis' work was to characterize the immune cells in these subjects and potentially find a trend of divergence between the fully durable and the transiently chimeric subjects. While most cell types showed no significant difference between the two groups, the post-transplant $\mathrm{CD}^{+}$naïve $\mathrm{T}$ cells and $\mathrm{CD} 4^{+}$regulatory $\mathrm{T}$ cells, that were measured, alluded to a pattern of divergence from pre-transplant levels. Despondently, because the transiently chimeric group had only four subjects, the range of data for the aforementioned cell types is extensive and no significant difference between the chimeric groups was able to be ascertained.

\section{Future Experiments:}

Due to the transiently chimeric group only having four subjects, it would be of scientific benefit to have a greater number of subjects that lost chimerism after transplant and before immunosuppressive therapy was ceased. While this is not ideal for subjects and the ultimate goal of the combined kidney + FCRx transplant model is to induce 
chimerism, a greater understanding of the aberration of the $\mathrm{CD} 8^{+}$naïve $\mathrm{T}$ cells and the $\mathrm{CD}^{+}$regulatory $\mathrm{T}$ cells of transiently chimeric subjects versus fully durable subjects may lead to the discovery of a predictive biomarker for chimerism.

There are other immune biomarkers that may possibly predict chimerism in subjects that received a combined transplantation. Dysregulation of miRNA levels in urine analysis has been observed in diseased conditions of kidney transplants [17] [18]. Elevated levels of the exosome neutrophil gelatinase-associated lipocalin (NGAL), have been shown to be early predictors of delayed transplant function [19]. Early detection of transplant rejection can be assessed by detecting low levels of PARP1 in the recipient's serum [20]. These potential biomarkers are minimally invasive, may detect transplant rejection at an early onset, and should be explored further. 


\section{SUMMARY AND CONCLUSION}

The characterization of select immune cells in subjects enrolled in the combined kidney + FCRx study has shown that naïve $\mathrm{CD} 4^{+}$, naïve $\mathrm{CD}^{+}$, and regulatory $\mathrm{T}$ cells repopulate at different rates between fully durable and transiently chimeric subjects post-

transplantation. While the limited number of subjects in the transiently chimeric group presented a shortcoming in the form of a wide range within those cell types, this work warrants further investigation to determine if naïve $\mathrm{CD} 4^{+}$, naïve $\mathrm{CD} 8^{+} \mathrm{T}$ cells, and or $\mathrm{CD}^{+}$regulatory $\mathrm{T}$ cells may potentially be a predictive biomarker for successful induction of chimerism. 


\section{REFERENCES}

1. Leventhal, J., et al., Tolerance induction in HLA disparate living donor kidney transplantation by donor stem cell infusion: durable chimerism predicts outcome. Transplantation, 2013. 95(1): p. 169-76.

2. Shlomchik, W.D., Graft-versus-host disease. Nat Rev Immunol, 2007. 7(5): p. $340-52$.

3. Bamgbola, O., Metabolic consequences of modern immunosuppressive agents in solid organ transplantation. Ther Adv Endocrinol Metab, 2016. 7(3): p. 110-27.

4. Engels, E.A., et al., Spectrum of cancer risk among US solid organ transplant recipients. JAMA, 2011. 306(17): p. 1891-901.

5. Leventhal, J.R., et al., Immune reconstitution/immunocompetence in recipients of kidney plus hematopoietic stem/facilitating cell transplants. Transplantation, 2015. 99(2): p. 288-98.

6. Mok, C.C., Therapeutic monitoring of the immuno-modulating drugs in systemic lupus erythematosus. Expert Rev Clin Immunol, 2016: p. 1-7.

7. Nankivell, B.J., et al., Calcineurin Inhibitor Nephrotoxicity Through the Lens of Longitudinal Histology: Comparison of Cyclosporine and Tacrolimus Eras. Transplantation, 2016. 100(8): p. 1723-31.

8. Ildstad, S.T., et al., Facilitating cells: Translation of hematopoietic chimerism to achieve clinical tolerance. Chimerism, 2015. 6(1-2): p. 33-9. 
9. Yolcu, E.S., J.R. Leventhal, and S.T. Ildstad, Facilitating cells in tolerance induction for kidney transplantation. Curr Opin Organ Transplant, 2015. 20(1): p. $57-63$.

10. Leventhal, J., et al., Evolving approaches of hematopoietic stem cell-based therapies to induce tolerance to organ transplants: the long road to tolerance. Clin Pharmacol Ther, 2013. 93(1): p. 36-45.

11. Chen, Y.B., T. Kawai, and T.R. Spitzer, Combined Bone Marrow and Kidney Transplantation for the Induction of Specific Tolerance. Adv Hematol, 2016. 2016: p. 6471901.

12. Bettelli, E., et al., Reciprocal developmental pathways for the generation of pathogenic effector TH17 and regulatory T cells. Nature, 2006. 441(7090): p. 235-8.

13. Reisner, Y., D. Hagin, and M.F. Martelli, Haploidentical hematopoietic transplantation: current status and future perspectives. Blood, 2011. 118(23): p. 6006-17.

14. Shapiro, R., et al., Alemtuzumab preconditioning with tacrolimus monotherapythe impact of serial monitoring for donor-specific antibody. Transplantation, 2008. 85(8): p. 1125-32.

15. Hoshino, J., et al., Using donor-specific antibodies to monitor the need for immunosuppression. Transplantation, 2012. 93(11): p. 1173-8.

16. Lee, P.C., et al., HLA-specific antibodies developed in the first year posttransplant are predictive of chronic rejection and renal graft loss. Transplantation, 2009. 88(4): p. 568-74. 
17. Kim, Y.K., Extracellular microRNAs as Biomarkers in Human Disease. Chonnam Med J, 2015. 51(2): p. 51-7.

18. Malyszko, J., et al., Biomarkers of delayed graft function as a form of acute kidney injury in kidney transplantation. Sci Rep, 2015. 5: p. 11684.

19. Alvarez, S., et al., Urinary exosomes as a source of kidney dysfunction biomarker in renal transplantation. Transplant Proc, 2013. 45(10): p. 3719-23.

20. Srivastava, M., et al., Reduced PARP1 as a Serum Biomarker for Graft Rejection in Kidney Transplantation. J Proteomics Bioinform, 2015. 8(2): p. 031-38. 


\section{CURRICULUM VITAE}

NAME: $\quad$ Mark DeWayne Badder

ADDRESS: $\quad 176$ Autumn Glen Dr.

Mt. Washington, KY 40047

DOB: $\quad$ Louisville, Kentucky - July 25, 1985

EDUCATION: Certificate of Phlebotomist

Jefferson Community College

Louisville, Kentucky

2013

B.S. Bioengineering

University of Louisville

Louisville, Kentucky

2009

Victory Christian Academy

Louisville, Kentucky

2003

PUBLICATIONS: Leventhal JR, Elliott MJ, Yolcu ES, Bozulic LD, Tollerud DJ, Mathew JM, Konieczna I, Ison MG, Galvin J, Mehta J, Badder MD, Abecassis MM, Miller J, Gallon L, Ildstad ST. 2015. Immune Reconstitution/Immunocompetence in Recipients of Kidney Plus Hematopoietic Stem/Facilitating Cell Transplants. Transplantation, Vol. 99, Pages 288-298.

ABSTRACTS: $\quad$ Joseph R. Leventhal, Larry Bozulic, Mark D. Badder, Mary Jane Elliott, Michael Issa, James Mathew, Iwona Konieczna, Suzanne T. Ildstad. Evaluation of Immunocompentence in Tolerant Chimeric Recipients of Hematopoietic Stem Cell/Renal Transplants. ASH 2013, New Orleans, LA, December 7-10, 2013. 
Leventhal J, Bozulic L, Badder M, Elliott MJ, Ildstad ST.

Evaluation of immunocompentence in tolerant chimeric recipients of hematopoietic stem cell/renal transplants. (Meeting Abstract). The American Transplant Congress, Seattle, WA, May 18-21, 2013.

Jazayeri M, Huang Y, Elliott MJ, Badder MD, Miller TO, Corbin DR, Ildstad ST. CD8+/TCR- bone marrow-derived facilitating cells improve ex vivo expansion of hematopoietic stem cells. (Meeting Abstract). Research!Louisville, Louisville, KY, September 19-21, 2012. 